\title{
The greening of Collor
}

São Paulo

FOR the first time, Brazil has agreed to accept "debt-for-nature swaps", in which up to $\$ 100$ million in outstanding loans will be retired each year in exchange for government spending on the environment.

The news from Brazilian president Fernando Collor de Mello came last week along with the announcement of several other environmental initiatives. Collor had just returned from the United States, where he was publicly criticized by US congressmen and environmentalists for not doing enough to curb devastation of the Amazon rain forest. These moves may help turn his image a shade greener.

Debt-for-nature swaps were anathema to the previous government of José Sarney, but with Brazil's external debt at $\$ 123,000$ million, the new government has reconsidered.

A key figure in the change of policy has been the new economy minister, Marcilio Marques Moreira, former ambassador to the United States, who has been more sympathetic to the environmental movement than many other Brazilian officials. In January 1989 , for example, he participated in a small ceremony in front of the US Capitol to honour the environmental activist Chico Mendes, who had been murdered the month before.

At the time, his actions seemed out of line with the tough stances taken by other offi-

\section{LIBRARIES}

\section{Museum still looking for stolen books}

\section{São Paulo}

THREE rare books stolen from the Museum of Zoology of the University of São Paulo have been recovered, but 26 others are still missing. The books, some of which are worth as much as $\$ \mathbf{2 0 0 , 0 0 0}$, all deal with birds and avian taxonomy.

The theft occurred on 8 March, but three of the books were found a month later at the auction house Christie's in New York, but the Brazilian press only recently learned of the case. The three books were found because a Christie's expert, Stephen Massey, thought it strange that they carried stamps of the Museu Paulista, the institution to which the Museum of Zoology was affiliated up to 1939.

The US Federal Bureau of Investigation and Interpol, the international police network, are looking for the other 26 books.

Brazilian police suspect that there is a gang specializing in stealing rare books from the badly protected libraries in this country. The books may be identified by stamps that say "Museu Paulista", "Museu de Zoologia" or "Universidade de São Paulo". Ricardo Bonalume cials, such as former foreign minister Abreu Sodré, who once said, "Brazil won't be the world's ecological preserve."

In the swaps announced by Collor, environmental groups or other governments will buy outstanding Brazilian debt on the secondary market, where it trades for little more than 30 per cent of its face value. The Brazilian government will then "pay off" the debt with local currency, putting about 75 per cent of the face value into accounts that will be used for various environmental purposes.

The money will be used to survey park boundaries, train guards and demarcate parks and Indian lands; some may go to research institutes. Belém's Museu Emilio Goeldi, for example, is barely functioning and part of its exhibition was closed to the public for lack of funds.

Along with the announcement of the swaps, Collor signed a decree forbidding tax subsidies for farm and cattle ranching projects that destroy the environment. The subsidies had been stopped in the beginning of his term but were re-initiated in April after pressure from supporters of the government.

Collor also fired Cantidio Guerreiro Guimarães, the head of Funai, the Indian protection agency.

Collor said the reason for the firing was that the agency head had failed to demarcate the lands of the Yanomami Indians, the largest tribe in the country, in the state of Roraima, near the border with Venezuela.

Cantidio Guerreiro says he was a scapegoat, fired to placate foreign critics and relieve international pressures. But he was considered to be a passive leader by those agency workers who live among the Indians and try to protect them from miners and farmers. The agency's number two man, Edivio Batistelli, who will succeed Cantidio Guerreiro, has a better record of dealing with the Indians and is considered to a better negotiator.

Collor's measures strengthen the position of his secretary for the environment, José Lutzenberger, who was chosen from the ranks of the country's environmentalists. The secretary had been criticized by some as a mere ornament in Collor's cabinet - a figurehead to appease foreigners. Now Lutzenberger will have his chance to prepare the country for next year's international meeting on biodiversity and the environment, to be held in Rio de Janeiro in June. It will be a chance for Brazil to cast off its image of international environmental villain - a reputation the country acquired with the extended burnings in the rain forest in 1988 and furthered by the killing of Chico Mendes.

This year's rainy season has just finished, and the dry season - suitable for burnings of forest areas - is about to begin. The next few months will tell much about Collor's commitment to the environment.

Ricardo Bonalume
More RU-486 now available for research Washington

ARE anti-abortion activists keeping the drug RU-486 out of the hands of researchers who want to test it for non-abortion uses? Absolutely, said organizers of a new organization created last month to oppose the current import ban on RU-486 for abortion use.

"The majority [of citizens] want RU-486 brought into the country for basic research. It's outrageous that you can't even test it," said Carol Rowen, a spokeswoman for the Los Angeles Coalition for RU-486, a collection of two dozen Californian health, abortion and women's groups who announced their joint campaign at a press conference.

But the coalition may have leapt before it looked. Although RU-486 availability may have once been a problem, it has been freely available to researchers for months, scientists say.

In support of their campaign, coalition organizers cite a congressional hearing by US Representative Ron Wyden (Democrat, Oregon) last November as proof of the RU-486 availability problem. At that hearing, researchers testified that they were finding it difficult, if not impossible, to obtain supplies of the drug from its French manufacturer, Roussel-Uclaf, because anti-abortion protesters had threatened the company with a boycott if it imported the drug into the United States (see Nature 348,$382 ; 29$ November 1990).

Since then, however, the outlook for RU-486 research has brightened considerably, something the coalition's organizers appear to have neglected to check out before launching their nationwide campaign.

"We don't have any problem anymore. We can get all we need." says George Chrousos, a National Institutes of Health researcher studying RU-486's use for Cushing's syndrome and one of the witnesses at the November hearing who testified that they had been unable to secure a supply of the drug. Other scientists who are studying RU-486 for breast cancer and other diseases agree: whatever the extent of the problem last year, neither RousselUclaf nor the US government appears to be standing in the way of legitimate research now.

Coalition organizers said they would look more closely into the issue. If they are unable to find a scientist with a complaint about RU-486 access, they say they will narrow their focus to the current import ban on the drug as an abortifacient. On that front they may find support easier to find. This spring, New Hampshire offered itself as a haven for RU-486 clinical testing for abortion, and a bill now pending in California would do the same.

Christopher Anderson 